\title{
Limiting the Number of Open Projects to Shorten the NPD Schedule
}

\author{
Miao-Ling Wang \\ Minghsin University of Science and Technology \\ Department of Industrial Engineering and Management, Hsin-Chu County, Taiwan 304, ROC \\ Tel: +88635593142\#3212, E-mail: wml@must.edu.tw \\ Chun-I Yang \\ AboCom Systems, Inc. Miao-Li County, Taiwan, ROC \\ E-mail: ken.yang56@gmail.com \\ Sheng-Hung Chang ${ }^{\dagger}$ \\ Minghsin University of Science and Technology \\ Department of Industrial Engineering and Management, Hsin-Chu County, Taiwan 304, ROC \\ Tel: +88635576581, E-mail: shchang@must.edu.tw
}

Received, January 19, 2011; Revised, February 19, 2011; Accepted, February 21, 2011

\begin{abstract}
Many companies open multiple projects simultaneously due to market trends, which results in a crowding out effect because of limited resources. $R \& D$ engineers become overloaded and scheduling of product development is delayed resulting in timing misses and lost sales leads. The company in this case study (Company A), often opens up many projects simultaneously in order to respond to market needs quickly. The engineers are overloaded and, of course, the schedule is delayed. In order to identify problems, Company A began using Dr. Goldratt's Thinking Processes (TP) during new product development (NPD). When the analysis phase of TP was completed, Company A's core problem was identified as "the quantity of kick-off projects." Consequently, new rules and conditions and procedures were proposed for the opening, suspending, stopping, and closing of projects. Finally, the "Future Reality Tree" ensured that the proposed rules, conditions and procedures were set up as an available solution approved for practical application by executives. After a one-year trial run, the results showed that the Project Duration Rate was reduced by 53\%, the Project Closed Rate was increased by $140 \%$ and the Project on Time Rate was increased from $10 \%$ to $68 \%$. The above results give significant evidence of the benefits of the proposed methodology.
\end{abstract}

Keywords: Thinking Process, Project Management, Rules to Open a Project, New Product Development

\section{INTRODUCTION}

The timely development of new products is an indicator of sustainable management for a company, and a key factor of success in competitive markets (Drucker, 1954). For the sake of efficiency, many companies use all kinds of management skills and tools to shorten the whole R\&D process (Reid and Shoemaker, 2006; Sambasivan and Soon, 2007). Company A is a network equipment manufacturer, whose main goals are to develop new products and produce them, and whose customers are famous brands and distributors worldwide. In order to respond to the changing demands of the markets,
Company A has always kicked-off as many as projects as possible with the goal of meeting customer needs. This practice of starting several projects simultaneously has led to crucial difficulties in the process of $R \& D$ that have resulted in serious schedule delays. Company A has struggled to solve this problem, with its department chiefs having little clue as to how to pursue it. Accordingly, Company A has thrown in more manpower to tackle the delay issues; however, this method is not working, because manpower has failed to meet its burden; even worse, engineers are too tired to problem solve (Goldratt, 1994).

Furthermore, multi-projects run at the same time

$\uparrow:$ Corresponding Author 
made bad multi-tasking and jeopardized the project's schedule and quality (Anavi-Isakow and Golany, 2003). In order to identify the fundamental issue, a panel was set up by the department chiefs of Company A, which we name the TP Panel. By carrying out in-depth interviews and discussions, the TP Panel found out that the core conflict was "the quantity of kick-off projects." Through the rigorous cause-and-effect logic of the Current Reality Tree, this conflict was then identified as the root cause of Undesirable Effects in Company A.

To resolve this problem, the Panel proposed the rule design of "opening, suspending, stopping, and closing projects," which was introduced as a step-bystep procedure for managing all projects. The program found that this rule and procedure effectively eliminated all the Undesirable Effects and Desirable Effects appeared, as shown through rigorous deduction and verification in the Future Reality Tree. Therefore, the Panel recommend-ded that this solution be run in Company A's new product development to overcome the problem of sche-dule delays.

This study draws on the release of a year's testing data to show that if the number of open projects is reduced and controlled properly, the proposed methodology will not only increase the resource utilization rate, but it will also shorten the development schedule. Moreover, when other problem-solving injections, such as on-job training, clear specifications, and more shared parts reinforced by the Future Reality Tree, are introduced to the proposed solution, the Project Duration Rate (PDR), the Project Closed Rate (PCR), and the Project on Time Rate (PTR) is improved even further, yielding more benefits for the company.

In the material that follows, this paper will explain how Company A applied a thinking process for seeking solutions to crucial problems. This process includes the identification of a core problem, the development of a solution, and the introduction of step-by-step rules and procedures to implement the solution. Finally we discuss the results of proposed solution as applied in Company A.

\section{SOLUTION METHODOLOGY}

A well-defined thinking process can organize complex issues, identify core conflicts, deliver solutions and thereby resolve the issues in the end (Walker II and Cox III, 2006; Kim et al., 2008; Li and Chang, 2005). This study aims to address the issue of new product development scheduling using the Theory of Constraints (TOC) thinking process methodology, the identification of Undesirable Effects through in-depth interviews, and the confirmation of a core problem through the ThreeCloud Process. A follow-up step is taken that utilizes the Current Reality Tree to confirm all Undesirable Effects that are linked, and to stimulate methods to solve the core problems. Finally, we verify whether or not the solutions can eliminate all Undesirable Effects by using the Future Reality Tree mapping tool and constructing a down-to-earth program for Company A. The subsections below describe the four main steps of our methodology, which are listed as follows: Pointing Out the Core Issue of Company A; Constructing the Solution; Designing Validation Rules and Conditions; and Introducing the Validation Process.

\subsection{Pointing Out the Core Issue of Company A}

Seven Undesirable Effects were found by the TP Panel of Company A. They include the following: Too many projects to be kicked-off; Frequent scheduling changes; Poor communication; Project delay; Frequent spec changes; Unbalanced loading; and Key parts hard to obtain. We selected three major Undesirable Effects for further discussion: "Too many projects to be kickedoff," "Poor communication" and "Frequent spec changes." The Three-Cloud-Process of converging these three conflicting clouds into a core conflict cloud is shown in Figure 1.

To verify and form the Current Reality Tree, rigorous causations were performed using logical deduction. During the construction of the Current Reality Tree, we found that the core conflict was "the quantity of kick-off projects." Since this conflict had connection with all the Undesirable Effects that linked, its identification as the core conflict was confirmed. It followed that if we could control "the quantity of kickoff projects" to a reasonable extent, we would be able to reduce the crowding out effect, increase the on-time rate of projects, and also overcome other problems.

\subsection{Constructing the Solution}

When identifying the core issues with the Current Reality Tree, we needed to brainstorm as many ideas as possible to break the core conflict. The generation of constructive ideas has another, less obvious purpose: it can bring a positive atmosphere to a company that leads to good performance. After TP panel discussion, a Great Idea came out that concerned the formation of rules, conditions, and procedures for "opening, suspending, stopping, and closing projects." These were constructed as standard operating procedures for departments to follow. Also, ways of ensuring departmental compliance and rule implementation were proposed in the formation proce $\$$. achieve the above goals, two main procedures were developed as follows:

\subsubsection{Injections Stimulation}

In the Current Reality Tree, the Great Idea proposed by the Panel represents an initial idea for breaking the core conflict. However, an idea does not always lead to good results. These require the introduction of supporting measures so that the Strategic Objectives of the 


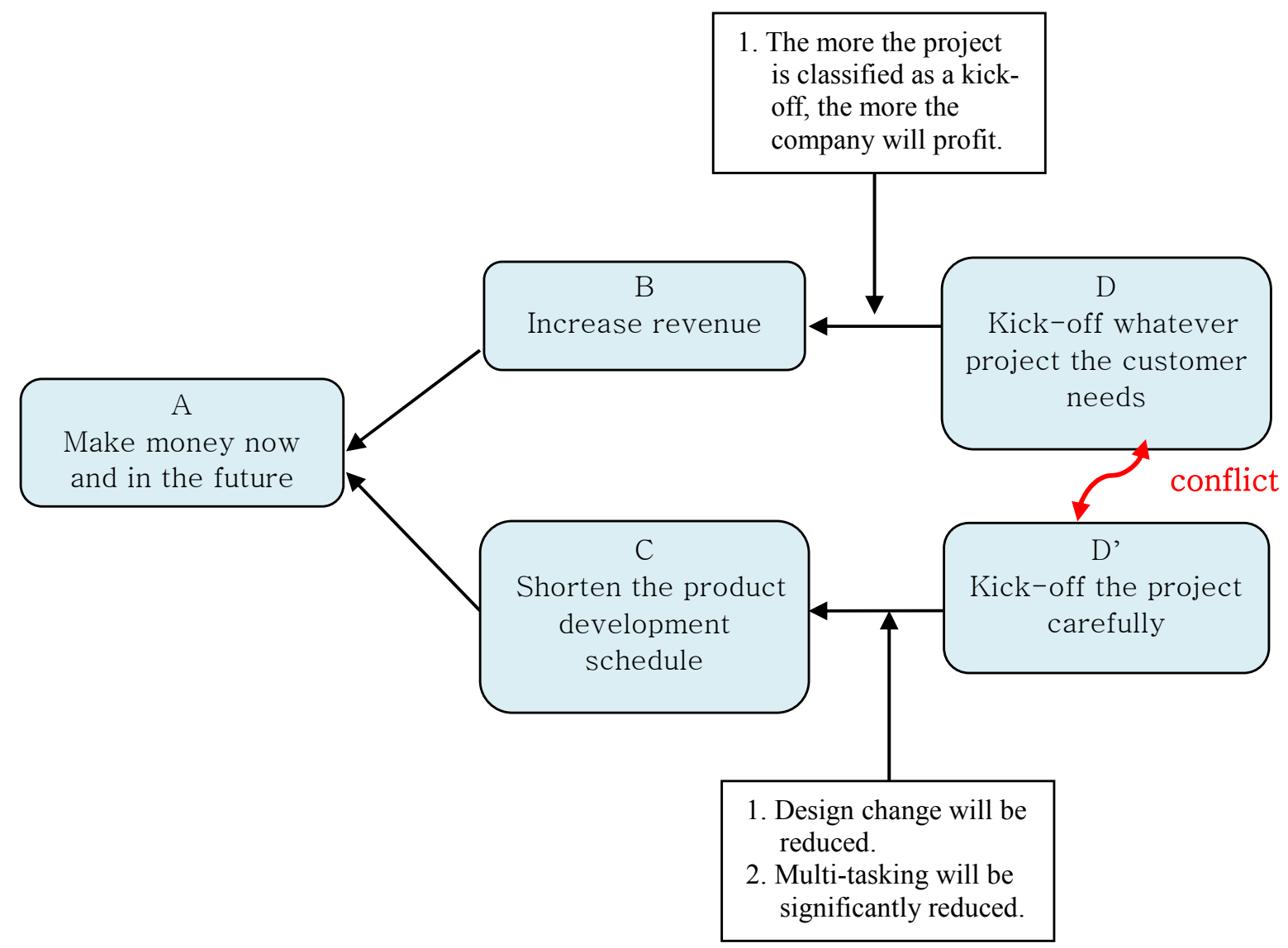

Figure 1. Core Conflict Cloud.

Great Idea can be reached. The Panel put forward nine supporting measures, which are described below:

[Injection 120] Each department follows up on the Kickoff rules.

[Injection 130] Clear specs are provided by clients.

[Injection 140] The RD engineers provide the correct Bill of Material (BOM).

[Injection 150] The BOM is maintained and up-to-date.

[Injection 210] There are clear rules for RD resources allocation.

[Injection 330] New employees are well trained.

[Injection 350] The status of the project returns correctly.

[Injection 360] A real-time project status report is given.

[Injection 510] The production team gets the parts ready early.

[Injection 620] There are more shared parts.

\subsubsection{Construction of the Future Reality Tree}

An idea not only requires supporting measures before it can be implemented. It also requires verification to determine whether the solutions (good ideas or injecti ons) can bring good results. The purpose of constructing a Future Reality Tree for Company A was to determine whether or not the Panel's solutions would have a posi- tive impact on the company. If these solutions or good ideas could lead to all the Desired Effects and reach the Strategic Objective, then the good ideas could be seen as objectives that need to be met. Examples that illustrate this statement are provided below:

The Future Reality Tree in Figure 2 shows that by incorporating Injection 130 "Clear specs are provided by clients" with Starting Injection 100 "Set up regulation to open, suspend, stop, and close project," Company A can reach Desirable Effect 220 "Project spec is firmed." If Injection 210 "There are clear rules for RD resources allocation" are obtained along with Desirable Effect 200 "Kick off projects are maintained in reasonable quantity," the company can achieve 300 "Everyone keeps limited tasks on-hand." Coupled with the Injection 330 "New employees are well trained," this will lead to the achievement of 400 "The RD engineer focuses on one task at a time." Again, if Company A obtains 310 "Rework reduced" and 320 "Spec change reduced," it can then reach 520 "Task duration reduced." Finally, incorporating Injection 620 "There are more shared parts" with Desirable Effect 610 "Parts are delivered on time by venders" will enable Company A to reach Strategic Objective 820 "WIP reduced." This will lead to the ultimate goal of Strategic Objective 1000, which states: 


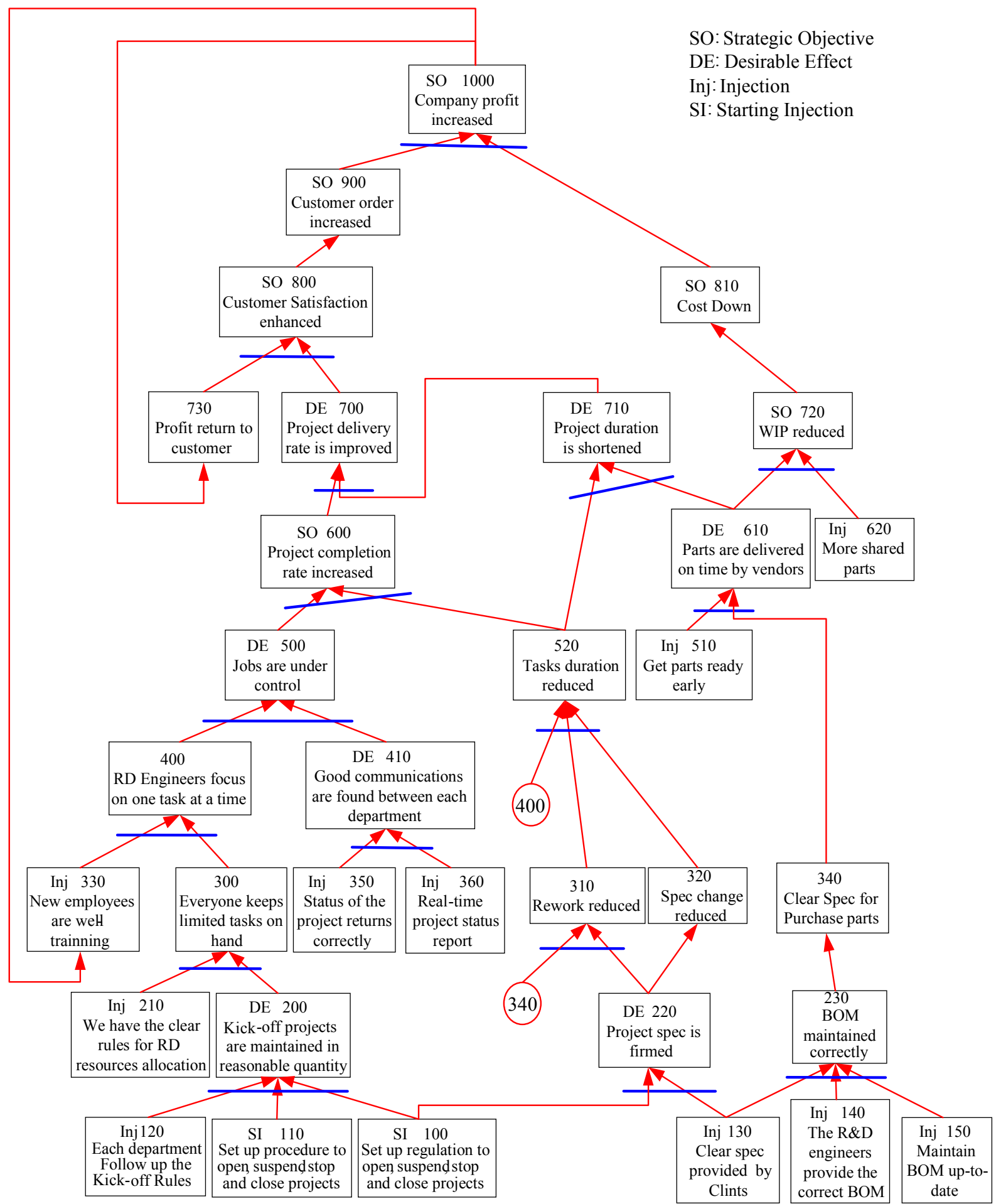

Figure 2. Future Reality Tree of Company A.

"Company profit increased."

This study showed that the Panel could eliminate all Undesirable Effects by the solutions they constructed, solutions that were later verified in the Future Reality Tree. By following the proposed method, Company A would be able to reach its Strategic Objective and 
achieve good results in the end.

\subsection{Designing Validation Rules and Conditions}

The results of the Future Reality Tree indicate that the Starting Injection is the first one to be validated when the rule and procedure of "opening, suspending, stopping, and closing projects" is made. This validation process is required so that the rules and conditions can be implemented. Other supporting measures also need to be taken to establish the step-by-step procedure that characterizes the solution to the core conflict. The details of these rules and procedures are described below:

2.3.1 Setting up Rules and Conditions for Opening, Suspending, Stopping and Closing Projects

We used Company A's web-based product projects as our case study, and selected all the projects those were opened during the study. The project rules and conditions are stated as follows:

- Conditions for Opening a Project

a) The documentation needs to be presented completely. When opening the case, all the necessary papers should be prepared and include project name, specifications, price, marketing, customers, profitability, and a product analysis of competitors.

b) When the quantity of opening cases is less than the total number of cases (including the stopped cases), this indicates a case shortage; hence, new cases can be opened.

c) To maintain a certain number of cases, we start a new project in the wake of finishing an old one.

- Conditions for Suspending a Project

a) The clients request it.

b) The problem continues happening over three weeks.

c) Development cost has exceeded $20 \%$ of estimation.

d) Market demand disappears.

- Conditions for Stopping a Project

a) Main Chip parts are replaced.

b) The project is suspended for more than 6 months.

c) Market demand disappears.

d) Clients cut the project.

e) The developing schedule is in excess of $50 \%$ of that evaluated.

- Conditions for Closing a Project

a) Pilot production product is completed and yields of $95 \%$ or more.

b) Project documents are intact and new product description meeting has been held.

2.3.2 Designing Procedures for Opening, Suspending, Stopping and Closing projects

- Procedure for Opening a Project
Opening a case needs to be evaluated and illustrated by meeting F0 (R\&D stage 0 ). If this Council re-jects the case, the case will be returned for reevaluation. If all the department chiefs in charge of these cases agree upon the case, meeting F1, whose main responsible is to assess the technical possibility and spending estimation, will be ready. If the F1 Council rejects the case, the project will be moved back to the department that presented it for reevaluation of the proposal; otherwise, the case can be officially opened.

\section{- Procedure for Suspending a Project}

The units that want to suspend a case must follow the rules stating the conditions under which cases are suspended, and call for a meeting. This meeting will send a formal suspension notice to departments that are connected with the case when the proposal is approved by departments of sale, development, and management. If it is not approved, the proposal will be returned to the original departments and evaluated again.

- Procedure for Stopping a Project

The departments that want to stop a case must follow the rule of procedure and call for meeting. This meeting will send a formal stopping notice to departments that are connected with the project when the proposal is approved by departments of sale, development, and management. If it is not approved, the proposal will be returned to the original departments for reevaluation.

- Procedure for Closing a Project

The departments that want to close a project must follow the rule of procedure and call for meeting. This meeting will send a formal closing notice to departments that are connected with the case when the proposal is approved by departments of sale, development, and management. If it is not approved, the proposal will be returned to the original departments for reevaluation.

\subsection{Introducing the Validation Process}

The verification procedures for Company A include Designing Introducing Process; Confirming the Calculation Basis and Performance indicators.

\subsubsection{Designing Introducing Process}

The validation process, as shown in Figure 3, first selects the projects to be included in the analysis, and then conducts data collection and analysis to provide information for project-reducing meeting. After feasibility evaluation, the meeting would determine whether the case would be reduced. If it does meet the suspending/stopping/closing criteria, it would be sent back to the original departments for re-assessment; otherwise, the data of the suspended/stopped/closed cases every month would be collected, and evaluation and analysis are performed until the validation period is over in order to generate final reports. 

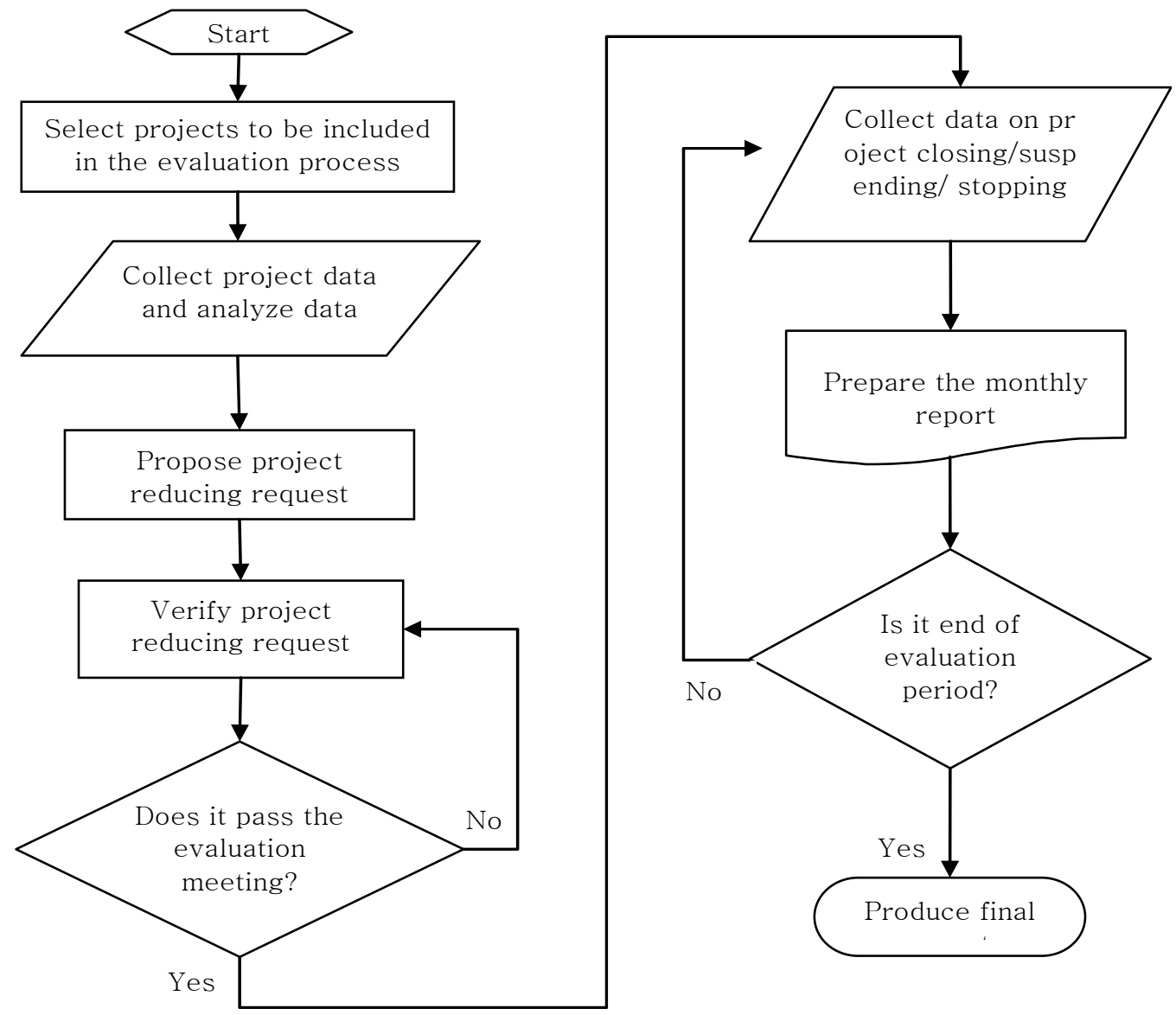

Figure 3. The Validation Process.

\subsubsection{Confirming the Basic Assumption and Performance} Indicators

\section{- Basic Assumption for Calculation}

The case study was carried out on projects between 2008/07 and 2009/05. Three classes of projects were excluded from this study: projects that dropped out accidentally for irresistible reasons; projects that closed accidentally for irresistible reasons; and projects with a stopping period not within our study period. The standard for staff loading was calculated as 10 hours, and $70 \%$ of this time was calculated as the working hours of a day; that is, engineers work on average seven hours a day, 22 days per month, and 132 days in a half year.

- Performance Indicators

a) Project Duration Rate (PDR): PDR is defined as the real hours of work per month divided by the estimated duration per month as follows:

$$
\text { PDR }=\frac{\text { actual duration per month }}{\text { estimated duration per month }}
$$

Where the "actual duration" denotes the summation real durations every month; the "estimated duration" denotes the summation durations of initially estimated projects.

The PDR value tends to be more accurate if it closely approximates 1 .

If PDR is less than 1, work is ahead of schedule; if it is greater, work is behind schedule. The PDR value is better if it is smaller.

b) Project Closed Rate (PCR): PCR is defined as the quantity of closed projects per time unit, as equation (2) shows:

$$
\mathrm{PCR}=\frac{\text { no. of closed projects }}{\text { study period }}
$$

Where the "no. of closed projects" denotes number of projects that were closed during the study period.

The PCR value is better if it is bigger.

c) Project on Time Rate (PTR): PTR is defined as the ratio of projects on-time to the total number of projects, as equation (3) shows: 


$$
\mathrm{PTR}=\frac{\text { no. of on }- \text { time projects }}{\text { total projects }}
$$

Where the "no. of on-time projects" denotes the number of projects that are on-time completed.

The PTR value is better if it is bigger.

\section{VALIDATION AND RESULTS}

This section describes the verification of the solutions that were proposed for Company A with regard to the development of new products. Verification was based on the introducing process, and included the projects status description, a project-cut step, and a performance analysis of the proposed methodology.

\subsection{Status Description}

Company A began the verifying procedure between 2008/07 and 2009/05, and there were 41 projects tracked. Some projects, because of special considerations, lead to long development times, and these were stopped; hence, they were not included in the calculation basis. Figure 4 compares two schedule charts: the real schedule and the predicted one from six months ago. The gray bar is the estimated time of when projects open and the oblique line bar is the actual time. A crosscheck of the two lines found that there were big differences between the two lines, and that the PDR could reach as high as 3.2.

\subsection{Project-Cut Step}

Before running the test case for Company A in real conditions, we preceded with the step of cutting projects according the rules mentioned above. Fourteen projects between 2008/07 and 2009/04 were cut; thus, the final number of projects for verification was 27 , indicating a cutting rate of around $34 \%$.

\subsection{Performance Analysis and Discussion}

\section{- Project Duration Rate}

The authors implemented the steps of opening and reducing cases from 2008/07 on. The PDRs gradually went down from an initial rate of 3.2 (shown in Figure 5). The records show that by 2009/02 working hours were lowered to 1.7 in terms of PDR, indicating a $47 \%$ reduction. Because company A conducted an organization restructuring in 2008/12, this study was suspended in 2009/01 and Company A reverted to the original project execution method; therefore, as the records show, PDR went up from 1.7 after 2009/02 and reached 2.4 in $2009 / 05$. We could see clearly that the changed solution procedure was the main factor responsible for the higher
PDR, and this gave evidence that our proposed methodology and strategy work.

\section{- Project Closed Rate}

The total number of closed projects between 2008/ 01 and 2008/06 was 6, and PCR was around 0.5 six months before the solutions were introduced. After we introduced the solution procedure in 2008/07, the PCR was stable at 1 2 projects per month (shown in Figure 6). The rate fluctuated, but the trend showed a significant increase. 12 projects were closed between 2008/ 09 and 2009/05, and the PCR was about 1.2, indicating a significant increase of $140 \%$. Similarly to the result obtained in terms of PDR, the records show that the PCR value was worse (i.e., low) between 2008/12 and 2009/ 01 when the proposed procedure was suspended due to organizational restructuring.

\section{- Project on Time Rate}

Before we introduced our solution procedure, most of the closed projects of Company A were delayed; the PTR was under $10 \%$. As Figure 7 shows, PTRs were under $90 \%$ in the early phase and then went up over $90 \%$ after the solution procedure was introduced. The average PTR was about $68 \%$, indicating a significant increase on previous results.

\section{CONCLUSION}

This study used Dr. Goldratt's Thinking Process to construct its causality with strict logical deduction, and to identify the source of conflict in companies. On this basis, it constructed solutions, introduced verified cases in Company $\mathrm{A}$, and made its observations using these results. A one-year trial run showed that the proposed methodology enabled Company A to improve dramatically in resource utilization, and to lower its Project Duration Rate as much as 53\%. Performance indicators showed similarly positive results. There was a $140 \%$ increase in the Project Closed Rate and a 68\% increase in the Project on Time Rate. Thus, the solution methodology proposed by this study not only allowed Company A to learn how to use the TOC thinking process to find the root causes of problems and eliminate them, but it also shows how companies can use solutions they design to enhance the whole company performance.

\section{ACKNOWLEDGEMENT}

The authors would like to thank the National Science Council of the Republic of China for financially supporting this research under Contract No. NSC 972622-E-159-002-CC3. 


\begin{tabular}{|c|c|c|c|c|c|c|c|c|c|c|c|c|c|c|c|c|c|c|c|}
\hline & D & 任務名程 & Duration & Start & Finish & Preder & $\frac{\text { March }}{M}$ & $\frac{\text { April }}{\text { A }}$ & May & June & ${ }_{\text {July }}$ & $\frac{A_{\text {August }}}{\mathrm{A}}$ & $\begin{array}{c}\text { September } \\
\text { \$ }\end{array}$ & $\begin{array}{c}\text { October } \\
0\end{array}$ & $\underset{N}{\text { November }}$ & $\begin{array}{c}\text { December } \\
\text { D }\end{array}$ & $\begin{array}{c}\text { January } \\
\text { J }\end{array}$ & $\begin{array}{c}\text { February } \\
\text { F }\end{array}$ & March \\
\hline 1 & & $\square$ TAP520P & 91 days & $08 / 5 / 16$ & $08 / 9 / 17$ & & & & & & & & 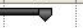 & & & & & & \\
\hline 2 & 国 & WAP520P-X1(Plan) & 49 days & $08 / 5 / 16$ & $08 \pi / 22$ & & & & $=$ & 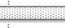 & 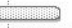 & & & & & & & & \\
\hline 3 & 国 & WAP520P-X1(Real) & 46 days & $08: 6 / 27$ & $08 / 8 / 28$ & & & & & & $\mathrm{am}$ & & & & & & & & \\
\hline 4 & 国 & WAP520P-X2(Plan) & 44 days & $08 \cap 21$ & $089 / 17$ & & & & & & & 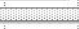 & 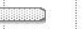 & & & & & & \\
\hline 5 & 国 & WAP520P-X2(Real) & 14 days & $08 / 8 / 28$ & 089116 & & & & & & & & 10 & & & & & & \\
\hline 6 & & & & & & & & & & & & & & & & & & & \\
\hline 7 & & E W05204 & 91 days & $08 / 4 / 14$ & $08 / 8 / 14$ & & & & & & & & & & & & & & \\
\hline 8 & 国 & WU5204-X1(Plan) & 34 days & $08: 4 / 14$ & $08 / 5,29$ & & & & 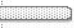 & & & & & & & & & & \\
\hline 9 & 目 & WU5204-X1(Real) & 34 days & $08 / 4 / 14$ & $0815: 29$ & & & & 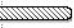 & & & & & & & & & & \\
\hline 10 & 国 & WU5204-X2(Plan) & 42 days & $08 / 5130$ & $08 \cap 25$ & & & & & & & & & & & & & & \\
\hline 11 & 国 & WU5204-X2(Real) & 0 days & $08 / 529$ & 081529 & & & & & $5 / 29$ & & & & & & & & & \\
\hline 12 & 国 & WU5204-D1(Plan) & 22 days & $08 \cap / 17$ & $08 / 8 / 14$ & & & & & & & & & & & & & & \\
\hline 13 & 国 & WU5204-D1(Real) & 45 days & $08 / 5130$ & $08 \cap / 30$ & & & & & & ate & & & & & & & & \\
\hline 14 & & & & & & & & & & & & & & & & & & & \\
\hline 15 & & $\square$ SDW 3100 & 184 days & $08 / / 2$ & 09/3/12 & & & & & & & & & & & & & & \\
\hline 16 & 回 & SDW3100-X1(Plan) & 24 days & $08 \pi / 2$ & $08 / 8 / 4$ & & & & & & 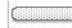 & & & & & & & & \\
\hline 17 & 国 & SDW3100-X1(Real) & 38 days & $08 \pi / 3$ & $08 / 8 / 22$ & & & & & & and & & & & & & & & \\
\hline 18 & 国 & SDW W100-X2(Plan) & 18 days & $088 / 1$ & $088 / 25$ & & & & & & & 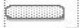 & & & & & & & \\
\hline 19 & 国 & SDW3100-X2(Real) & 24 days & 088825 & $089: 25$ & & & & & & & & 8 & & & & & & \\
\hline 20 & 国 & SDW W100-X3(Plan) & 0 days & $08 / 9125$ & $08 / 9125$ & & & & & & & & & $9 / 25$ & & & & & \\
\hline 21 & 国 & SDW3100-X3(Real) & 57 days & $08 / 10 / 3$ & $08 / 12 / 20$ & & & & & & & & & aाए & & & & & \\
\hline 22 & 国 & SDW3100-D1(Plan) & 13 days & $08 / 9 / 23$ & $08 / 1019$ & & & & & & & & & S & & & & & \\
\hline 23 & 国 & SDW3100-D1(Real) & 45 days & $09 / 19$ & $09 / 3 / 12$ & & & & & & & & & & & & & & \\
\hline 24 & & & & & & & & & & & & & & & & & & & \\
\hline 25 & & $\square \mathbf{Y B} 300 \mathrm{~T} / \mathbf{R}$ & 157 days & $08 / 3 / 28$ & $08 / 10 / 30$ & & & & & & & & & & & & & & \\
\hline 26 & 国 & VB300T/R-X1(Plan) & 57 days & $08 / 3 / 28$ & $08 / 6 / 16$ & & & 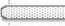 & & 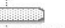 & & & & & & & & & \\
\hline 27 & 国 & VB300T/R-X1(Real) & 155 days & $08 / 4 / 1$ & $08 / 10 / 30$ & & & & & & & & & & & & & & \\
\hline 28 & 国 & VB300T/R-X2(Plan) & 40 days & $08 / 6 / 19$ & $08 / 8 / 11$ & & & & & & & & & & & & & & \\
\hline 29 & 国 & VB300T/R-X2(Real) & 0 days & $08,6 / 17$ & $08: 6 / 17$ & & & & & $\diamond 6$ & & & & & & & & & \\
\hline 30 & 国 & VB300T/R-X3(Plan) & 40 days & $08 / 8 / 12$ & $08 / 10,6$ & & & & & & & & & & & & & & \\
\hline 31 & 馬 & VB300T/R-X3(Real) & 0 days & $08 / 6 / 17$ & 086117 & & & & & $\diamond 6$ & & & & & & & & & \\
\hline 32 & & & & & & & & & & & & & & & & & & & \\
\hline 33 & & $\square$ VB301 T/R & 107 days & $08 \% / 16$ & $08 / 11 n$ & & & & & & & & & & & & & & \\
\hline 34 & 园 & VB301 T/R-X1(Plan) & 26 days & $08,6 / 16$ & $08 \pi 18$ & & & & & & $\infty$ & & & & & & & & \\
\hline 35 & 国 & VB301 T/R-X1(Real) & 46 days & $08 / 6 / 17$ & $088 / 15$ & & & & & & & 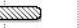 & & & & & & & \\
\hline 36 & 国 & VB301 T/R-X2(Plan) & 45 days & $08 \pi / 21$ & $089 / 26$ & & & & & & & & 2.... & & & & & & \\
\hline 37 & 国 & VB301T/R-X2(Real) & 0 days & $08 \cap 21$ & $08 \cap 21$ & & & & & & & $7 / 21$ & & & & & & & \\
\hline 38 & 国 & VB301 T/R-X3(Plan) & 40 days & $08 / 9 / 15$ & $08 / 11 \pi$ & & & & & & & & & & & & & & \\
\hline 39 & 国 & VB301 T/R-X3(Real) & 0 days & $089 / 15$ & $089 / 15$ & & & & & & & & $\diamond 9 / 15$ & & & & & & \\
\hline
\end{tabular}

Figure 4. Project Schedule.

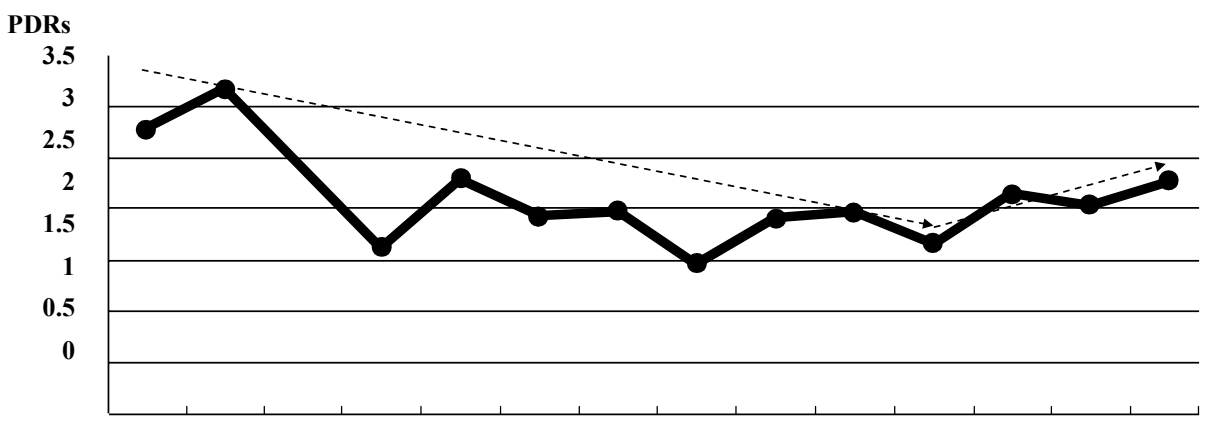

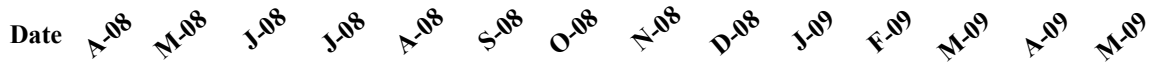

Figure 5. Project Duration Rate by Month's.

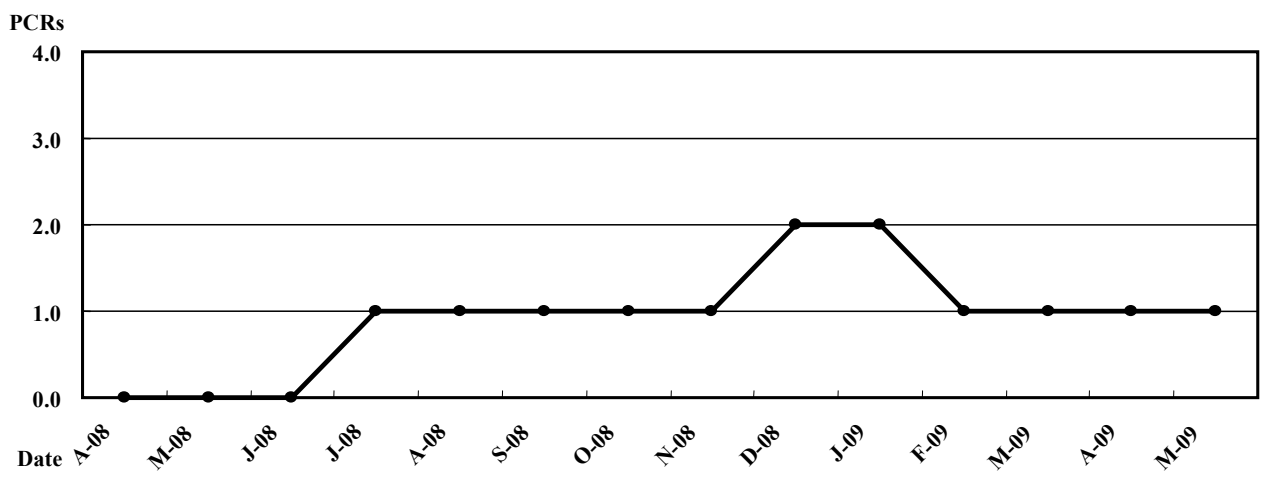

Figure 6. Project Closed Rate by Month's. 


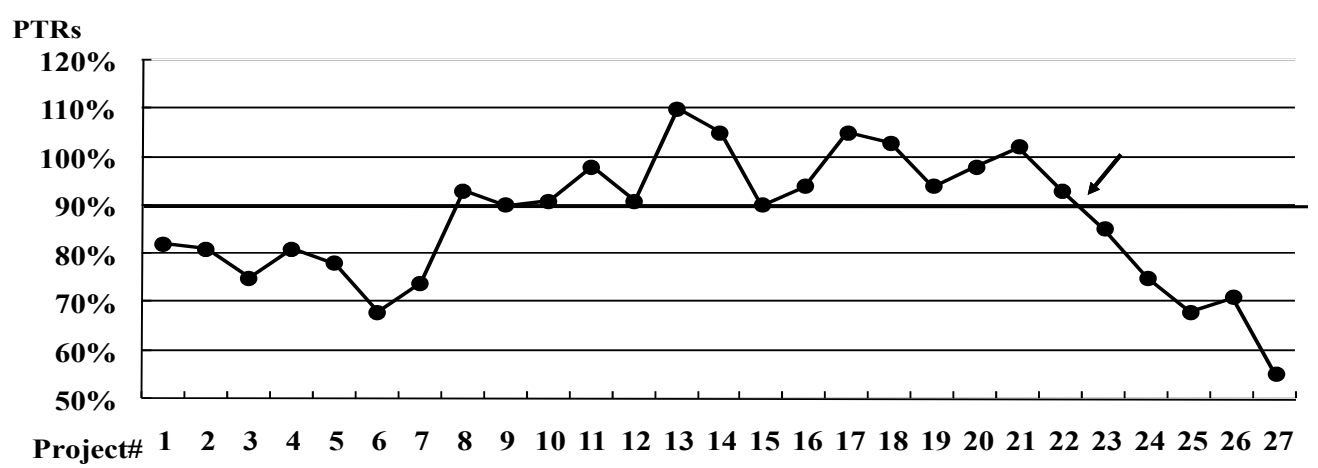

Figure 7. Project on Time Rate(All Project's).

\section{REFERENCES}

Anavi-Isakow, S. and Golany, B. (2003), Managing multiproject environments through constant work-inpro-cess, International Journal of Project Management, 21, 9-18.

Drucker, P. F., (1954), The Practice of management, Harper and Row Publishers Inc. New York.

Goldratt, E. M. (1994), It's Not Luck. Gower, England.

Kim, S., Mabin, V. J., and Davies, J. (2008), The theory of constraints thinking processes: retrospect and prospect, International Journal of Operations and Production Management, 28, 155-184.

Li, R. K. and Chang, S. H. (2005) Theory of Constraints -from limited to unlimited. The China Productivity
Center Taiwan ROC.

Reid, R. A. and Shoemaker, T. E. (2006) Using the Theory of Constraints to focus organizational improvement efforts: Part 1-Defining the problem, Journal of American Water Works Association, 98, 6375.

Sambasivan, M. and Soon, Y. W. (2007) Causes and effects of delays in Malaysian construction industry, International Journal of Project Management, 25, 517-526.

Walker II, E. D. and Cox III, J. F. (2006) Addressing illstructured problems using Goldratt's thinking processes: A white collar example processes, Management Decision, 44, 137-154. 